Res. Newsl., 9(2): 15-16.

Poorani, J. (1990). Prey Influence on the Development and Biology of Cyrtorhinus lividipennis Reuter, a Predator of Rice Leaf and Planthoppers. Unpublished M.Sc. (Ag) Thesis, Tamil Nadu Agricultural University, Madurai, 116pp.

Prasad, M. and Varshney, R.K. (1995). A check-list of the Odonata of India includiing data on larval studies. Oriental Ins., 29: $385-428$.

Ramakrishna Ayyar, T.V. and Krishna Ayyar, P.N. (1933). $A$ Preliminary list of the Insect Fauna of Coimbatore. Madras: The Agricultural Department, 197pp.

Tyagi, B.K. (1997). Dragonfly wealth of India - Extant species. A preliminary systematic list. Zoos' Print 12(10): 3-10.

\section{SPOTTING OF THE GIANT WOOD SPIDER (NEPHILA MACULATA) IN THE GUINDY NATIONAL PARK, CHENNAI}

\author{
V.S. Venkatraman and Vena Kapoor \\ Centre for Indian Knowledge Systems, 47-C, Gandhi Mandapam Road, \\ Kotturpuram, Chennai, Tamil Nadu 600085, India \\ E-mail:ciks@giasmd01.vsnl.net.in
}

The Guindy National Park (GNP) consisting of 270.57 ha. of Reserved Forest is one of the last refuges of a tropical dry evergreen forest type of the Coromandel Coast. The biodiversity within the Park is quite amazing despite the fact that it is a very small area surrounded by concrete jungles and human habitations. Today, these exert intense pressure directly and indirectly to the Park.

An ecological study on invertebrates with special emphasis on Arachnids (spiders and their relatives) is currently in progress in the Reserved Forest area of Guindy National Park. An important aspect of this study is to observe and record predatory habits and habitat assocations of different species of spiders. It has been found that these animals play an important ecological role as insectivores (Nyffeler \& Benz, 1987) but surprisingly, the basics of spider predation ecology is still largely unknown for most species.

It was during this study that we came across a spider, which has

Received 25 January 1999;

Accepted 7 March 1999 so far not been seen or recorded in GNP. A female Giant Wood Spider (Nephila maculata) was spotted in all her glory. The Giant Wood Spider was first spotted on the 3rd of November 1998 during which time the monsoon had begun in the city. The Nephila species has the distinction of building the largest orbweb with a span of about $1.5 \mathrm{~m}$. This species is a conspicuous feature of tropical environments, the massive female with her stocky, elongated, beautifully marked body catching the attention of many a photographer. The total body length of this spider (excluding legs) can go upto $36-45 \mathrm{~mm}$, with the male of this species only about $10-12 \mathrm{~mm}$ ! The total body length (including legs) of the individual spotted was measured to be $75 \mathrm{~mm}$. The habitat of this species is around bushes and trees in thick, wooded forests and has usually been observed in higher altitudes with cooler climatic conditions. Only a solitary female was spotted by us for 5 days and searches around the area of sighting for any other individuals were in vain. Readings of the length and span of the web, the length of the individuals, and the height of. the web from ground level were recorded (Table 1). We also noticed her feeding on a moth and, on a subsequent day, feeding on an Earhead Bug (Leptocorisa sp.)

Table 1. Dimension and position of Nephila maculata web

\begin{tabular}{llll}
\hline Data & 5 Nov. '98 & 6 Nov. '98 & 7 Nov. '98 \\
\hline $\begin{array}{l}\text { Length } \\
\text { breadth: }\end{array}$ & 26 inches & 20 inches & 22 inches \\
$\begin{array}{l}\text { hub ht. from } \\
\text { ground level }\end{array}$ & 102 inches & 31 inches & 37 inches \\
\hline
\end{tabular}

The fact that this particular species was found in isolation and to our knowledge not been spotted in GNP eariler prompted us to make the following notes.

References to previous articles and literature show that the Nephila sp. has so far usually been recorded in high altitudes, at least in southern India. " 17 females amd 3 males were collected from the Nilgiri district 1000ft. above sea level in October 1961". (Phanuel, 1963). Ray Sherriffs (1918) in his Contribution to the Study of Arachnology, 1918, has recorded Nephila maculata only in Dolosbage, Ceylon (3000ft.).

\section{Acknowledgement}

We would like to thank our guide, Dr. Vijayalakshmi and the Wildlife Warden, Ms. Mita Banerjee for their encouragement and support.

\section{References}

Nyffeler, M. and G. Benz (1987). Spiders in natural pest control: A review. J. Appl. Entomol. 103: 321-339.

Phanuel, G.J. (1963). Studies on the Arachneida of Madras.

Ray Sherriffs, W. (1918). A contribution to the study of South Indian Archnology. 